\title{
Building Information Modelling Uptake: Tool Training in Nigeria
}

\author{
Mansur Hamma-Adama ${ }^{1 *}$, Tahar Kouider ${ }^{1}$, Huda Salman $^{1}$ \\ ${ }^{1}$ Robert Gordon University, Aberdeen, United Kingdom \\ *Corresponding author: Mansur Hamma-Adama: m.hamma-adama@rgu.ac.uk
}

\section{OPEN ACCESS}

Citation: Hamma-Adama M., Kouider T., Salman H. (2018) Building Information Modeling Uptake: Tool Training in

Nigeria.Open Science Journal 3(3)

Received: $30^{\text {th }}$ May 2018

Accepted: $13^{\text {th }}$ July 2018

Published: $5^{\text {th }}$ September 2018

Copyright:@ 2018 This is an

open access article under the terms of the Creative Commons

Attribution License, which permits unrestricted use, distribution, and reproduction in any medium, provided the original author and source are credited.

Funding: The author(s) received no specific funding for this work

Competing Interests: The author have declared that no competing interests exists.

\section{Abstract:}

Computer Aided Design software and their kind are generally considered as Building Information Modelling (BIM) tools; moreover the sophistication level of one determines its maturity level. Education and research are the background to innovation while training is a window to continuity in skills transfer. The BIM uptake in the developing countries is significantly lagging behind; amongst various reasons is the lack of trained professionals. Experts are evolving from the industry professionals who are first trained in the university. This study determined the capacity of Nigerian universities in providing BIM tools training for BIM adoption in Architecture, Engineering and Construction (AEC). The study is quantitative in nature, with the primary data collected through a structured questionnaire survey within the built environment and engineering schools of Nigerian universities. The collected data were analysed using descriptive statistics. The institutions are physically ready with relatively sufficient hardware, however technically not ready due to insufficiency of up to date software. There is a significant correlation between software availability and proficiency level of training, while no correlation between academic qualification and the training proficiency. More than $70 \%$ of the students are graduating on 'file based collaboration' $-2 \mathrm{D}$ and $3 \mathrm{D}$ CAD knowledge with proficiency level between limited and practical application. However, the collaborative software training received proficiency level of basic to practical application; a $13 \%$ trained on collaboration software is very little to providing experts for the industry. This reveals a clear setback in the tools training to carter for the BIM uptake in the country. 
Keywords: BIM adoption, BIM tools, CAD training, Nigerian universities, proficiency level

\section{Introduction}

Computer Aided Design (CAD) begun in the 1960s. Since then, technologies have continued to evolve, with the main change being from Computer Assisted Drawing to Computer Aided Design. CAD technologies development are driven by the industries' applications (particularly, manufacturing) but research still remains the basis. Major manufacturing companies strongly backed the development of CAD systems at their early stage (Ye et al, 2004). Regardless of how the CAD technology and the industry evolve, students in universities want to acquire technologies that can best aid their career.

Rossignac (2004) identified many benefits to education-driven research in $\mathrm{CAD}$, amongst which is helping students to understand the core aspects quickly and be able to put what they learn to good use immediately. It is a source of instant gratification and motivation for a student to practise and learn more in this way. Although it could be difficult to providing necessary needs to include Building Information Modelling (BIM) training in university education, at the same time it is the right step to preparing the future employees (built professionals) for the industry (Construction, 2008).

Barison and Santos (2010) reported on a 2007 BIMForum survey of eight US academic institutions on their level of BIM training, it was found that more than $80 \%$ of them teaches BIM in their courses, and even the minority $(<20 \%)$ had introduced BIM in their teaching curricula since 2002. This of course has helped the US to be at the forefront of BIM adoption and also with its widespread use even before the government legislated on it (Casey, 2008; Construction, 2014). However, developing nations are lagging behind in BIM awareness, adoption and BIM experts (Eadie et al., 2013; Froise and Shakantu, 2014); could that be due to shortage of knowledge? Consequently, lack of BIM software skills poses great challenge to graduating students.

It can be understood that CAD knowledge and skills needed by students vary from profession to profession, person to person, job to job, and perhaps the CAD related roles they may perform in their subsequent careers (Ye et al, 2004). But all students should receive training on the rudiments of CAD and methodology of design. It is the university's responsibility to offer a wide range of specialist knowledge to students, while it is the responsibility of students to enhance their knowledge in some or specific areas (Dankwort et al, 2004).

This study aims to determine the capacity of Nigerian universities to provide BIM tools training for BIM adoption in AEC through an assessment of institutions' infrastructure (hardware and software) capacity; skilled/manpower capacity; $\mathrm{CAD}(\mathrm{s})$ training proficiency levels; as well as the outcome of the trained graduates of the built environment and engineering. 


\section{Literature Review}

\section{General CAD knowledge and impact}

The survey carried out by Ye et al (2004) shows that all CAD users have some knowledge of computer hardware. Although it is helpful for them to acquire the fundamentals, it is also necessary for them to be hardware experts. Moreover, CAD users do not need to have any programming skills and knowledge. The survey also reveals that over $70 \%$ of the participants thought that CAD should have been taught more, especially in terms of physical training and application development. A number of their comments are given below:

"In general, current CAD education and training in colleges are far from adequate. Some colleges are still just teaching students simple $2 D$ drawing skills like AutoCAD. Even though some colleges have switched to $3 D$ packages, the syllabus they present to students is not comprehensive and systematic. It is somewhat hard for students to get a big and clear picture of the CAD."

"In the curriculum, the focus is entirely on CAD tools and skills (how to draw line...), rather than the application of CAD to engineering, or theory of $C A D$. Students came out of the class with knowledge of what buttons to push, but not how to use the CAD software to enhance the design process, and with very little knowledge of how CAD works." (Ye et al., 2004, pp.1457)

In the US, the number of practising engineers was more than one million thirteen years ago. Over the years, computers have played a significant role in their day to day jobs; their CAD usage varies from "not at all" to being "highly dependent" (Field, 2004). Moreover, CAD innovation has found its way not only into industries but also into higher institutions in different ways, and has been taught in different disciplines for different applications and with different foci (Ye et al, 2004). CAD technologies may be taught explicitly as a tool for design, drawing and drafting in architecture and engineering disciplines.

Ogunsote et al revealed that the training or modules (BIM related) offered to undergraduate students in Nigerian universities generally falls within introduction to computer science I and II, computer programming I and II, introduction to CAD, computer in architecture and AutoCAD (2007). Hence, they proposed additional modules across the years of study for architectural schools. However, Oladele (2009) recommended a curriculum review but one that focused on preservation of socio-cultural backgrounds in order to respond to societal needs while adopting the global principles (i.e. innovations) where necessary. 
Table 1: Proposed curriculum for Nigerian Schools of Architecture (Ogunsote et al., 2007)

\begin{tabular}{|c|c|c|}
\hline Level & 1st Semester & 2nd Semester \\
\hline 100 & Introduction to Basic Computing & Computer Graphics in Architecture \\
\hline \multirow[t]{2}{*}{200} & Introduction to CAD & Integration into 200L Studio Project \\
\hline & & Elective \\
\hline \multirow[t]{2}{*}{300} & Introduction to $2 \mathrm{D}$ CAD for & Integration into 300L Studio Project \\
\hline & Architecture & Elective \\
\hline \multirow[t]{2}{*}{400} & Introduction to $3 \mathrm{D} \mathrm{CAD}$ for & Integration into 400L Studio \\
\hline & Architecture & Project/ITF Elective \\
\hline \multirow[t]{2}{*}{500} & Visualisation and Animation in & Integration into final year project \\
\hline & Architecture & \\
\hline
\end{tabular}

Moreover, electives modules were also recommended to enhance proficiency in specific software, a suggestion which vindicated Dankwort's assertion (2004). These include:

- Mastering CorelDraw!

- Mastering Microsoft Publisher

- Introduction to AutoCAD

- Advanced AutoCAD

- Introduction to ArchiCAD

- Advanced ArchiCAD

- Mastering 3D Studio Max

The study by Onwuka revealed that it is engineering students who suffer the most in terms of exposure to appropriate teaching. The curricula of engineering programmes in Nigerian universities consist mainly of the fundamentals of mathematics, natural sciences and technology. This is good and very necessary but training does not end at the fundamentals (2009). The poor feedback received from employers of engineering graduates in terms of their fitness and confidence to work in the industry is evidence of the lack or inadequate amount of engineering applications in their educational curricula. Subjects such as structured programming, elements of architecture as well as computer methods in civil engineering (computer application in the design of structures) for civil engineering are woefully absent from curricula.

\section{How to train students on BIM tools and why}

A better but expensive way of CAD training is with a practical course (faceto-face) with guidance from an instructor (Dankwort et al, 2004). Several advantages can be derived from a practical course, such as direct feedback, direct interaction and the ability to satisfy students' curiosity to learn more. Graduates with little knowledge of application packages typically face challenges in entering the industry. However, these challenges are also determined by the size of a company; generally, the bigger or more specialised a company is, the more tailored CAD training there is available. Dankwort et al (2004) present a graph of a typical CAx-education of a new employee in a bigger company as shown in Figure 1 below: 


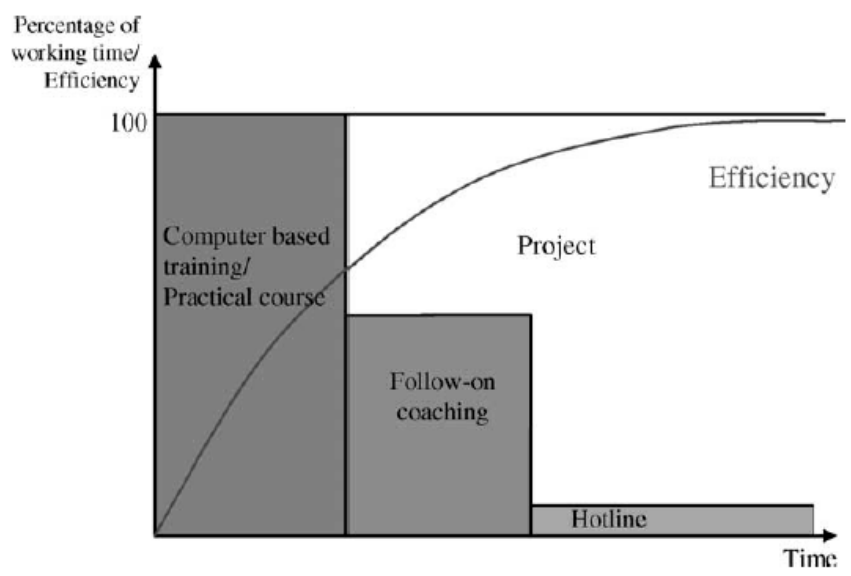

Figure 1: A typical CAx-education and the efficiency of a new employee

(Dankwort et al, 2004)

As a tool, BIM requires fundamental domain knowledge. Clevenger et al (2010) believe that core construction concepts should be taught in new teaching modules while acquiring knowledge for the industry's best practices rather than having only software tutorials. Engineering students take many mathematical modules which are fantastically relevant to their core knowledge as well as computer training abilities. Field (2004) feels that everyone using CAD needs a highly developed sense of spatial reasoning which can be achieved through mathematical knowledge.

Design methods and procedures are generally taught in universities, and the fundamentals are also included. However, the CAD technological aspect is missing and needs to be included (Dankwort et al., 2004). Although "design knowledge" is generally taught in universities as a general package because in the future practice, companies special necessities are diverse.

The procedure and methods used for design in the industry are never adopted as a formal method as they are taught in universities. Companies consider it highly beneficial if students were taught possibly in more than one of the standard systems; it is also important that students would have worked with sequences of CAD systems (for modelling, designing and data exchange) from university (Dankwort et al., 2004).

From the inception of CAD, manufacturing industries have been heavy users of it; it was known as "Design Augmented by Computers" at General Motors in order to stress the design being done by humans and computation by computers (Field, 2004). Construction (2008) associated the slow adoption of BIM in the industry with the lack of proper training. However, there is significant progress in this area by architectural technology schools which are leading the way in terms of the inclusion of BIM in their educational curricula (Construction, 2014). In contrast, engineering and construction schools are lagging behind significantly.

This might not be the case because construction industry itself is known to be fragmented and resistive to changes (Egan, 1998; Walasek and Barszcz, 2017). This is sometimes explained by the risk adverse nature of the industry in which many are sceptical about changing the way they work.

Most of the findings on reasons for non-inclusion of BIM in universities' curricula (Sabongi and Arch, 2009) are related to the following:

$>\quad$ No room in the current curriculum for additional classes 
$>\quad$ Lack of time or resources for the faculty to develop a new curriculum

$>\quad$ Constraint to additional required or elective module and still graduate in eight semesters

$>\quad$ Unavailability of resources specifically on BIM for students' use

Therefore, it is apparent that adopting new BIM based modules in AEC would be difficult. This is not only because of the above challenges but also because the cost of investment is high (Migilinskas et al, 2013). The cost of BIM investment is quite high even at industry level, although its return on investment is also high, specifically on big projects (Cao et al, 2014). Therefore, investing at institutional level might not be possible, although educational packages (i.e. Autodesk Educational versions) could be an alternative. Moreover, the requirement at institutional level is not to be expert but to acquire basic skills (Dankwort et al, 2004).

In the US, BIM tools training have been incorporated into universities' curricula. For instance, the Auburn University in Alabama incorporated BIM into its construction management curriculum so that students are required to learn a BIM software package to complete their project schedule and estimates based on their chosen software (Clevenger et al, 2010). A pilot implementation of BIM in the curriculum of the construction management department of Colorado State University was also carried out in order to promote BIM-enabled learning. This represented a way of meeting the requirements of both students and industry. Developing some modules/courses to replace previous conventional graphical courses proved positive (Sacks and Barak, 2009) as did integrating the BIM concept with other courses (Barison and Santos, 2010) which, it was argued, is what schools should do (Camps, 2008).

This contrasts with many developing nations which are lagging behind in BIM awareness and adoption, and also lack BIM experts (Froise and Shakantu, 2014). Lack of BIM software skills have posed a great challenge to students graduating in recent years. Several survey findings demonstrate discontent with curricula development regarding BIM (in relation to technical advancement) among students and educators (Sabongi and Arch, 2009; Sylvester and Dietrich, 2010).

Curricula of architectural schools need to be reviewed to produce CAD proficient graduates. In Nigerian universities specifically, lack of facilities and their maintenance for CAD training as well as funding were considered as major setbacks to CAD training (Ogunsote et al, 2007; Ogunrayewa, 2013). The National Universities Commission (NUC) and the Architects Registration Council of Nigeria (ARCON) have guidelines for accreditation of architectural programmes. The prerequisites include having adequate physical infrastructure such as laboratories and studios and relevant equipment; the same for classrooms and lecture theatres; as well as manpower with different qualifications and experiences (Ogunrayewa, 2013). However, attention has not focused on availability of software/CAD training which is linked to the industry's emerging and current challenges. Ogunrayewa describes the current state of teaching:

"... teaching of architecture as a course of study in a Nigerian university dates back to the 1960s. Although slight changes were being effected in the ensuing years, the curriculum on architectural education has largely remained the same" (Ogunrayewa 2013, pp.8).

Over ten years ago, Ogunsote et al (2007) concluded that many schools of architecture already had large computer laboratories, while practically all schools 
had computers. Therefore, the problem of poor CAD proficiency among lecturers had come to an end because most lecturers had their own PCs. Computers are now everywhere; the students themselves have their own but it is the availability of application software (i.e. AutoCAD, Revit, etc) which is critical to training and this is lacking. Three years after this study, Clevenger (2010) revealed students' inputs to be the best way to accomplish an incorporation of BIM in their courses through the combination of "creating a standalone BIM that discusses varieties of BIM uses with emphases on the use of software; and additional modules to the existing ones to deliberate how the BIM is relevant to the subject/area of study". The study further found that the primary objective of BIM teaching modules is

“...to enhance educational communication effectiveness by employing visual and interactive teaching techniques to illuminate core concepts while, simultaneously motivating and exposing students to BIM-enabled working processes and industry opportunities" (Clevenger et al, 2010, pp.4)

In their study, Rezgui et al (2010) concluded that knowledge management adoption in the AEC sector is creating value which is done through knowledge sharing. At the same time, training and educational systems must also evolve in parallel with CAD development (Field, 2004).

\section{BIM stages}

There are three well-defined revolutionary stages to achieving BIM capabilities. They are: object-based modelling (stage 1), model-based collaboration (stage 2), and network-based integration (stage 3). These stages are achieved with different technological processes (Succar and Kassem, 2015), and the technological advancement and sophistication required at each stage grows by stage (from 1 to 3 ), as do the investment and deliverables. Moreover, BIM stage is expressed as a minimum capability of a team to deliver a quantifiable result (Succar, 2009).

\section{Research Methodology}

The purpose of the survey was to determine the level of BIM software/tools training received by students (from engineering and built environment schools) in Nigerian higher institutions of learning for BIM adoption in the Nigerian construction industry. The research is quantitative in nature and its approach is analytical. The primary data for the investigation were obtained from instructors/tutors/lecturers in the Nigerian universities through a questionnaire survey. To avoid bias, the respondents were chosen randomly from higher institutions of learning in the country where civil, mechanical and electrical engineering as well as environmental courses were taught. A structured questionnaire was used to extract information based on the research question.

The questionnaires were randomly distributed across 46 universities that offered engineering courses (civil, electrical and mechanical) including 33 where architectural technology was taught. The questionnaire targeting tutors in those departments was typed and distributed by email along with an online survey version prepared in 'Google Docs'. A link was incorporated in the email which 
allowed for survey completion online rather than by email return. The "established emails" were compiled from randomly selected institutional websites.

The number in the target audience (considering at least one representative from each department) can be broken down as follows:

There were 46 institutions offering engineering courses;

3 engineering departments were considered (civil, electrical and mechanical);

33 schools of architectural technology

$\Rightarrow \quad 46^{*}(3)+33=171$ (departments) as sample size - respondents.

$\Rightarrow \quad 39 / 171=23 \%$ response, beyond $12 \%$ (liberal condition) according to Nulty (2008).

Out of the 54 distributed questionnaires, 39 responses were received (some by email and some by completing the online version). This represents $72.2 \%$ response rate which is considered adequate for the study to progress (Ballantyne, 2003). This satisfied both the $55 \%$ for paper-based response rate and $47 \%$ for online response rate.

There is a study underway to determine the level of awareness and adoption of BIM. This study is part of a preliminary study for doctorate research that explores the level of BIM infiltration in the Nigerian construction industry. The approach was through interviews with some key players in the industry. One of the respondents lamented the lack of skilled and confident graduates on BIM tools. Therefore, to adopt such way of working, staff must be trained on the new process hence became difficult to adopting it.

The above assertion by the respondent necessitates an enquiry to assess the students' training in this context. The enquiry was done through a questionnaire survey and it was designed and presented based on the research areas outlined below:

$>$ Infrastructure for training (abilities: personnel, computer lab., computer hardware \& software)

$>\quad$ Proficiency level of training (input)

$>\quad$ Proficiency level at graduation (output)

The respondents were engaged to assess the availability and capacity of their hardware and software, after which the proficiency level of training delivered to students as well as the training outcome of the courses were assessed.

The multiple choice, close-ended questions were drafted and sent directly to individuals' (lecturers) emails. The respondents were mainly from the following areas of the country: North-west, North-central and South-west in sliding order of quantity, then with very few from North-east and South-east. Therefore the result may not reflect the true picture of the entire country but most of its parts.

The surveys were prepared and sent electronically. A total of 54 emails were sent, out of which a total of 39 responses were collated which represents a $72.2 \%$ response rate; very adequate for this study according to Ballantyne (2003). The responses were distributed based on professions considered in the industry; the responses received from building departments were 2 which represents $5.1 \%$, architectural departments returned 10 (25.7\%), land/quantity surveying departments returned $2(5.1 \%)$, and engineering departments returned $25(64.1 \%)$. 


\section{Analysis and discussion}

\section{Survey findings}

The survey revealed that $82.1 \%$ of the respondents were lecturers; while $17.9 \%$ were technicians and technologists; over $70 \%$ of the lecturers had qualifications ranging from M.Sc. to Ph.D., and fewer than 30\% were first degree holders. A summary of the demographic profile of the respondents is presented in Table 2 below.

Table 2: Demographic Profile of Respondents $(\mathrm{N}=39)$

\begin{tabular}{lcrr}
\hline & & $\boldsymbol{n}$ & $\boldsymbol{\%}$ \\
\hline Respondent affiliation & Architecture & 10 & 25.60 \\
& Building & 2 & 5.10 \\
& Engineering & 25 & 64.10 \\
& Land Surveying & 1 & 2.60 \\
Cadre & Quantity Surveyor & 1 & 2.60 \\
\hline \multirow{2}{*}{ Academic qualification } & Lecturer & 32 & 82.10 \\
& Technologist & 7 & 17.90 \\
\hline & BSc/B. Tech. & 9 & 23.10 \\
& M.Sc. & 24 & 1.50 \\
& Ph. D & 6 & 15.40 \\
\hline
\end{tabular}

More than $50 \%$ of the respondents were experienced tutors, ranging from 5 years to over 15 years in academia. Below are bar charts (Figure 2 and Figure 3) representing respondents' cadre and academic qualifications, respectively.

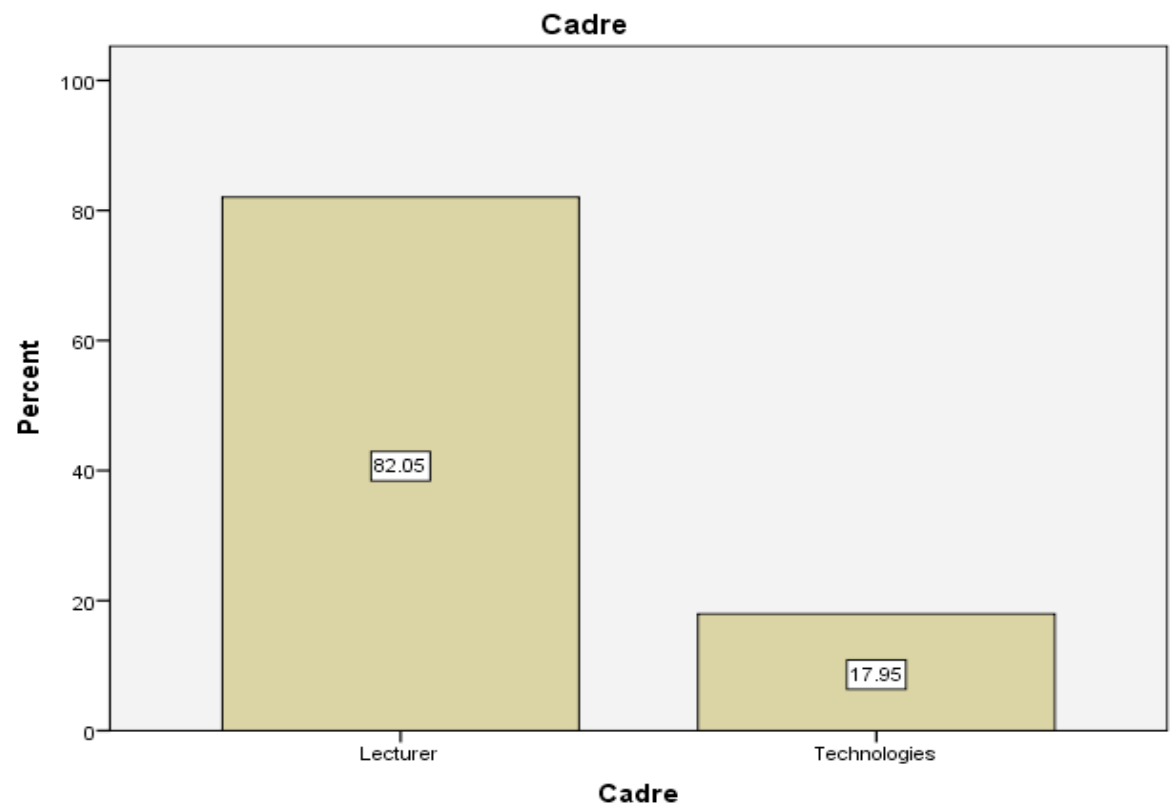

Figure 2: The respondents' cadre from Nigerian universities 


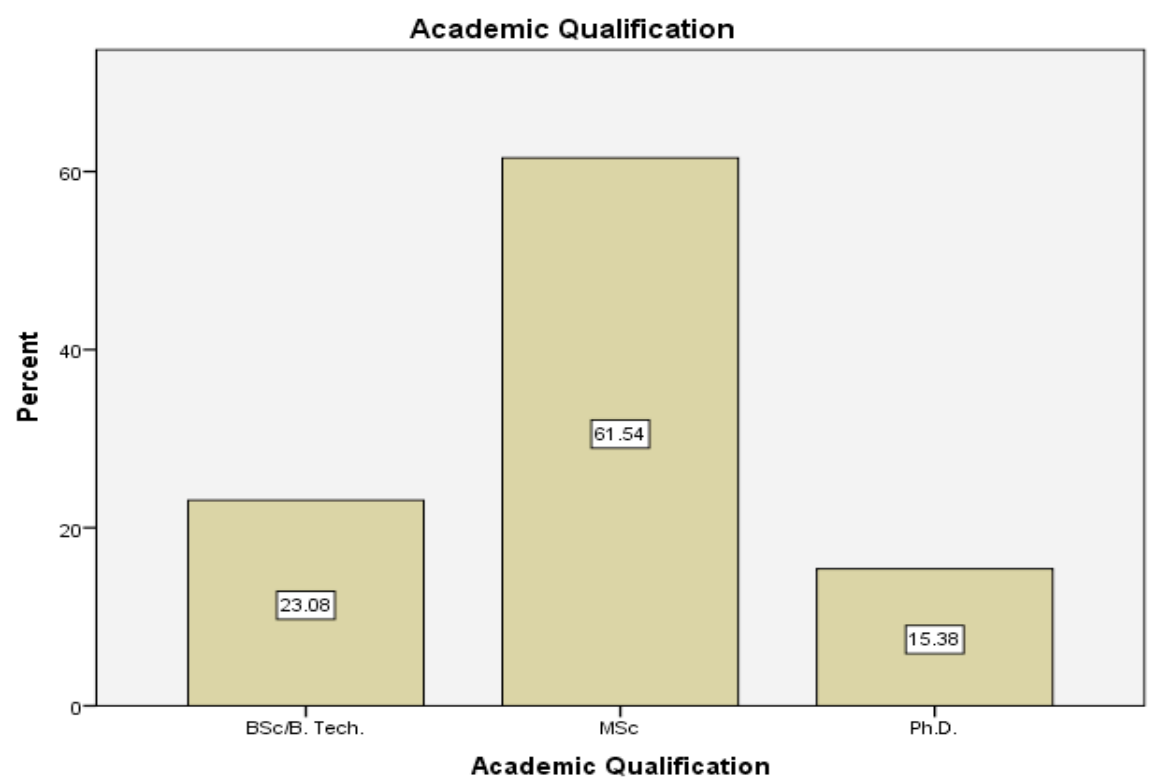

Figure 3: The respondents' academic qualifications

Below is a bar chart (Figure 4) illustrating rates and distribution of respondents: Architectural technology recorded a higher response rate at individual career level; this can be seen to be associated with a keen interest in the subject matter. Engineering departments constituted over $60 \%$ of the responses, perhaps because of a number of disciplines involved in the engineering profession (civil, electrical and mechanical); followed by architectural technology $(25.7 \%)$ and the remaining contributed $10.2 \%$. However, when individual courses (splitting engineering into three branches) are considered, architectural technology can be measured as the highest ranked.

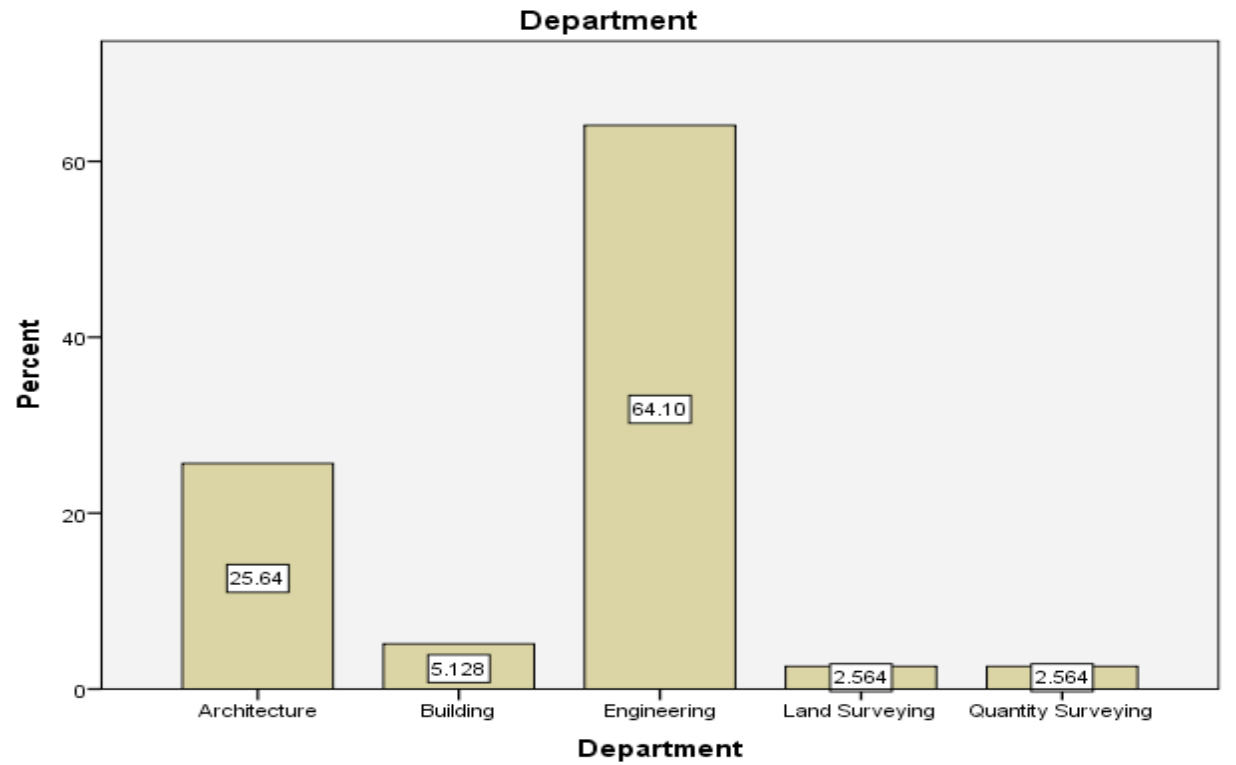

Figure 4: Distribution of the respondents 
In terms of training capacity, it was discovered that $77 \%$ of the institutions had relatively adequate computer laboratories as represented in the bar chart (Figure 5) below. About $44 \%$ of the schools had more than $30 \mathrm{PCs}$ in their respective laboratories (Figure 6) but only 20\% happened to have modelling software in their PCs (Figure 8), while only $13.3 \%$ of the students were enrolled for such (modelling) software training.

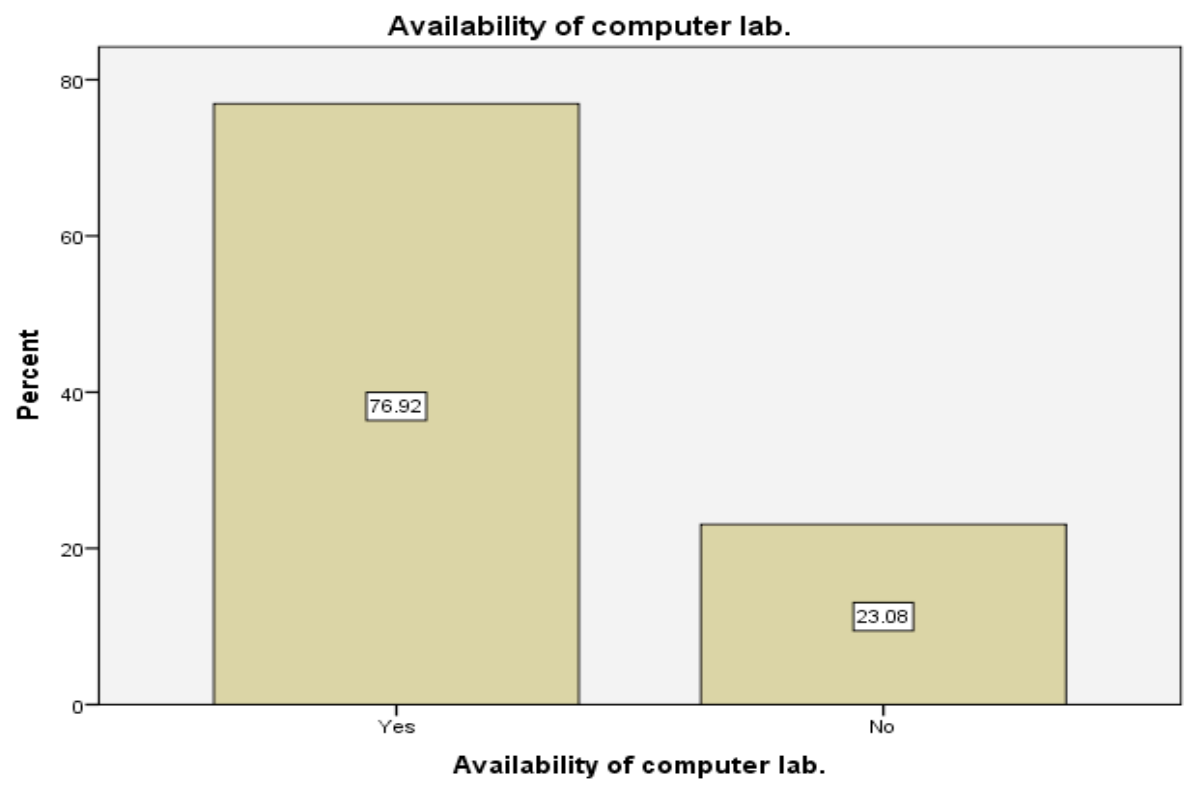

Figure 5: Availability of computer laboratory in the subject departments

With over $40 \%$ of the departments having more than 30 computers for training, a reasonable number of schools can therefore be considered to be hardware sufficient or relatively with enough computers for training. A statistical distribution can be seen in Figure 6 below.

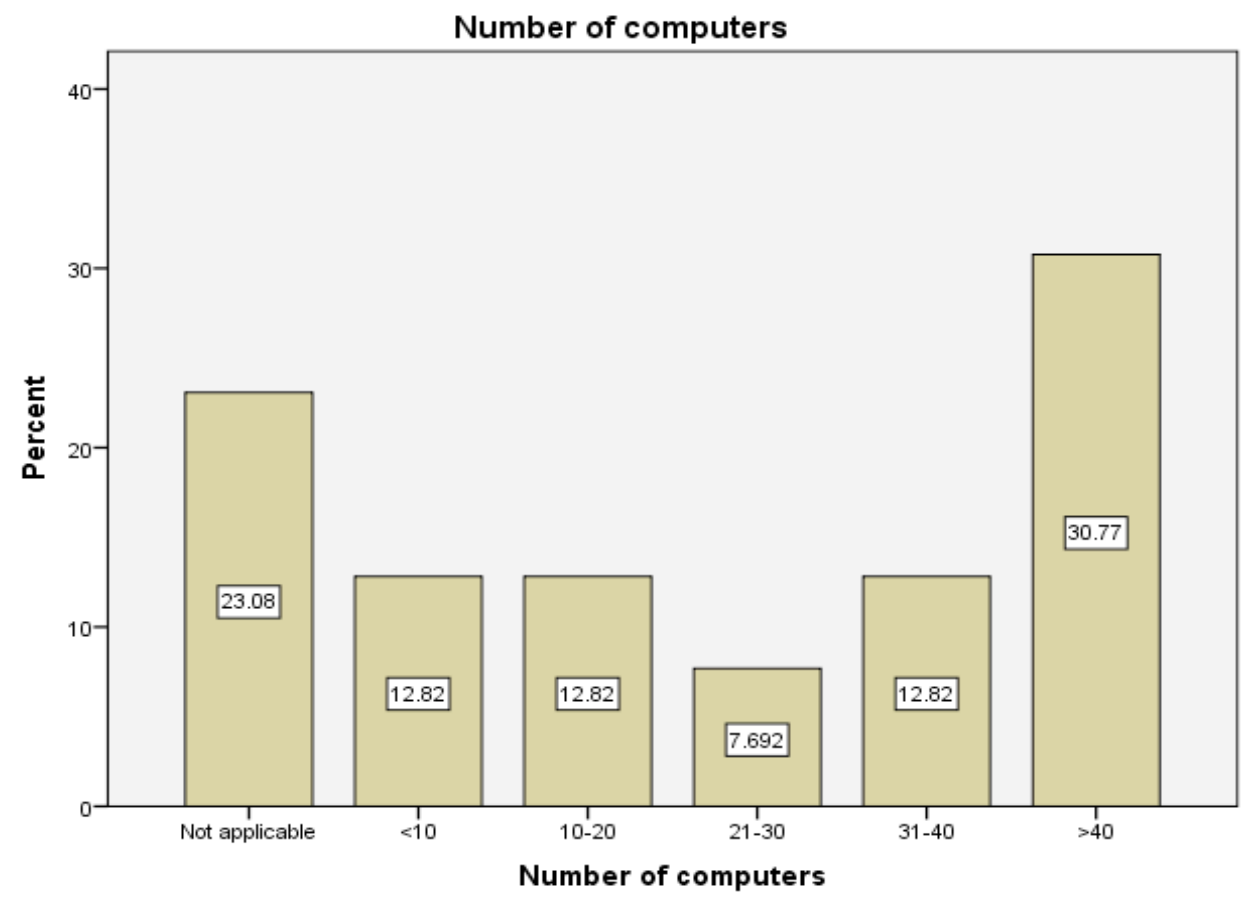

Figure 6: The quantitative capacity of the computer laboratories 


\section{Proficiency of application software training}

From Figure 7 below, it can be observed that the intermediate, fundamental awareness as well as novice topped the proficiency level of training offered to students. However, higher percentages of deficit can be noted at fundamental and intermediate levels (the yield was lower than the efforts). Hence, students receiving intermediate and fundamental awareness level of training experienced an output challenge; their outputs were less than the inputs $(43.3 \%$ to $33.3 \%$ and $36.7 \%$ to $30 \%$ respectively). However, the novice, advance and expert received greater outputs than there were inputs $(16.7 \%$ to $23.3 \%, 3.3 \%$ to $6.7 \%$ and $0 \%$ to $3.3 \%)$. This indicates the possibility of some trained students advancing their proficiency level; this positivity was noted as associated with the type of software available (advanced software) and the student computer ratio.

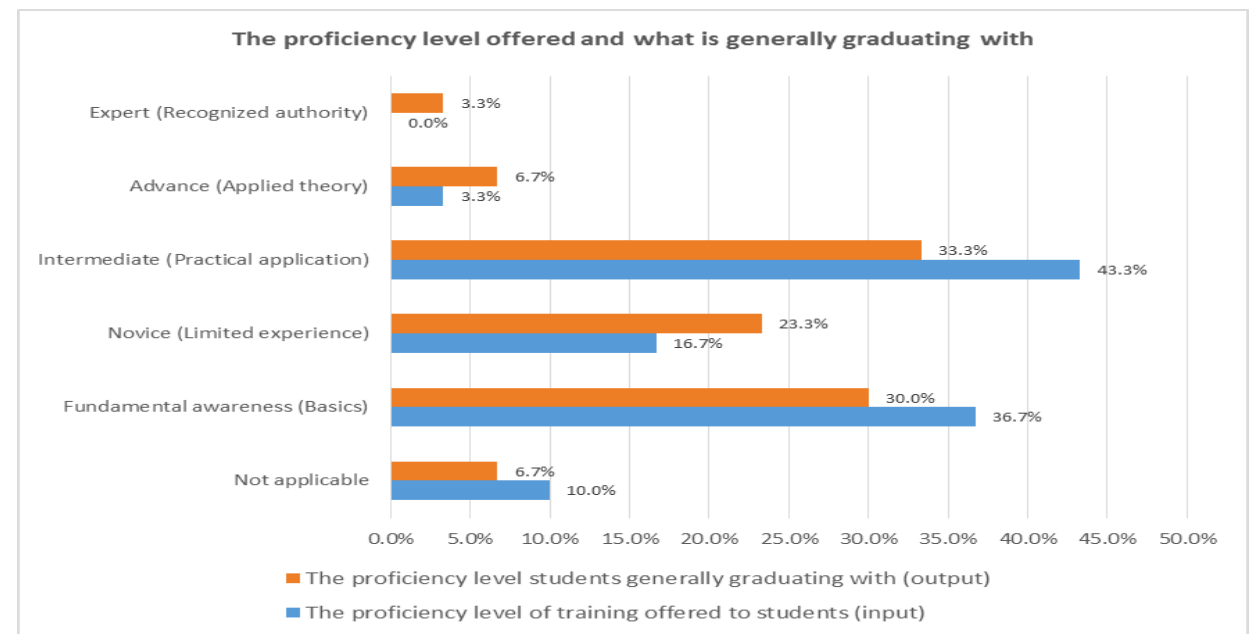

Figure 7: Proficiency level offered and what is generally graduated with

It can also be seen that $2 \mathrm{D} \mathrm{CAD}$ is a basic tool of all the institutions that offered application software packages training to students, with not more than $73.3 \%$ receiving training on $2 \mathrm{D}$ CAD basics up to application level. For the 3D CAD training, everyone trained on $3 \mathrm{D}$ CAD was equally trained on $2 \mathrm{D} \mathrm{CAD}$ as well. This means that those trained on 3D CAD were the subset of those trained on 2D CAD. To ascertain those trained on 2D CAD only, the following calculation is necessary:

$73.3 \%$ for $2 \mathrm{D}$ CAD in general

$36.7 \%$ for $3 \mathrm{D} \mathrm{CAD}$

$73.3 \%-36.7 \%=36.6 \%$ for $2 \mathrm{D}$ CAD only

$36.7 \%(3 \mathrm{D} \mathrm{CAD})+36.6 \%(2 \mathrm{D}$ CAD only $)=73.3 \%$ for both $2 \mathrm{D}$ and $3 \mathrm{D} \mathrm{CAD}$ training.

In summary, $73.3 \%$ of students were graduating with 2D CAD knowledge, thus acquiring limited and basic knowledge. Moreover, over half of the schools $(53.3 \%)$ had 3D CAD software which was normally incorporated with 2D CAD, but only $36.7 \%$ were training students on 3D CAD (up to practical application). On the other hand, less than a quarter of the institutions were observed to have a collaboration software (Revit Arch, Struct, MEP) with this, and only about half of them enrolled for such software training, perhaps due to a shortage of 
trainers or experts. Figure 8 below presents the variations in software availability and usage.

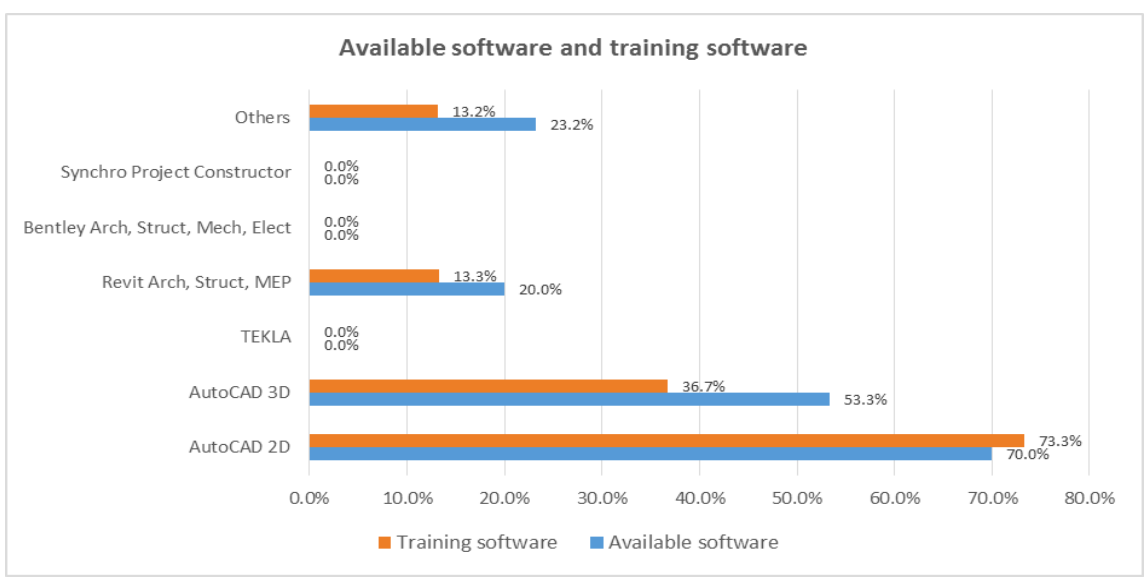

Figure 8: The available software packages and the training software

The t-test carried out to check for a correlation between the provision of software for the training and the proficiency of training acquired at graduation rejected the null hypothesis $\left(H_{o}\right)$. Table 3 refers to this.

Table 3: Paired Samples Test

\begin{tabular}{|c|c|c|c|c|c|c|c|c|c|}
\hline & & \multicolumn{5}{|c|}{ Paired Differences } & \multirow[t]{3}{*}{$\mathrm{t}$} & \multirow[t]{3}{*}{ df } & \multirow[t]{3}{*}{ Sig. (2-tailed) } \\
\hline & & \multirow[t]{2}{*}{ Mean } & \multirow[t]{2}{*}{$\begin{array}{c}\text { Std. } \\
\text { Deviation }\end{array}$} & \multirow[t]{2}{*}{$\begin{array}{l}\text { Std. Error } \\
\text { Mean }\end{array}$} & \multicolumn{2}{|c|}{$\begin{array}{c}95 \% \text { Confidence Interval } \\
\text { of the Difference }\end{array}$} & & & \\
\hline & & & & & Lower & Upper & & & \\
\hline Pair 1 & $\begin{array}{l}\text { Highest software } \\
\text { for training - } \\
\text { Proficiency at } \\
\text { graduation }\end{array}$ & .487 & 1.189 & .190 & .102 & .873 & 2.558 & 38 & .015 \\
\hline
\end{tabular}

The $t=2.558$ means $t$ falls within the rejection region for null hypothesis, hence there is a correlation in the population as $H_{o}$ is rejected. Moreover, the correlation is significant at the 0.01 level (2-tailed).

To fully present the impact of availability of software on the proficiency training received by the students, a multiple plot (Figure 9) is generated to explicitly present its rippling effect over the total responses in time. 


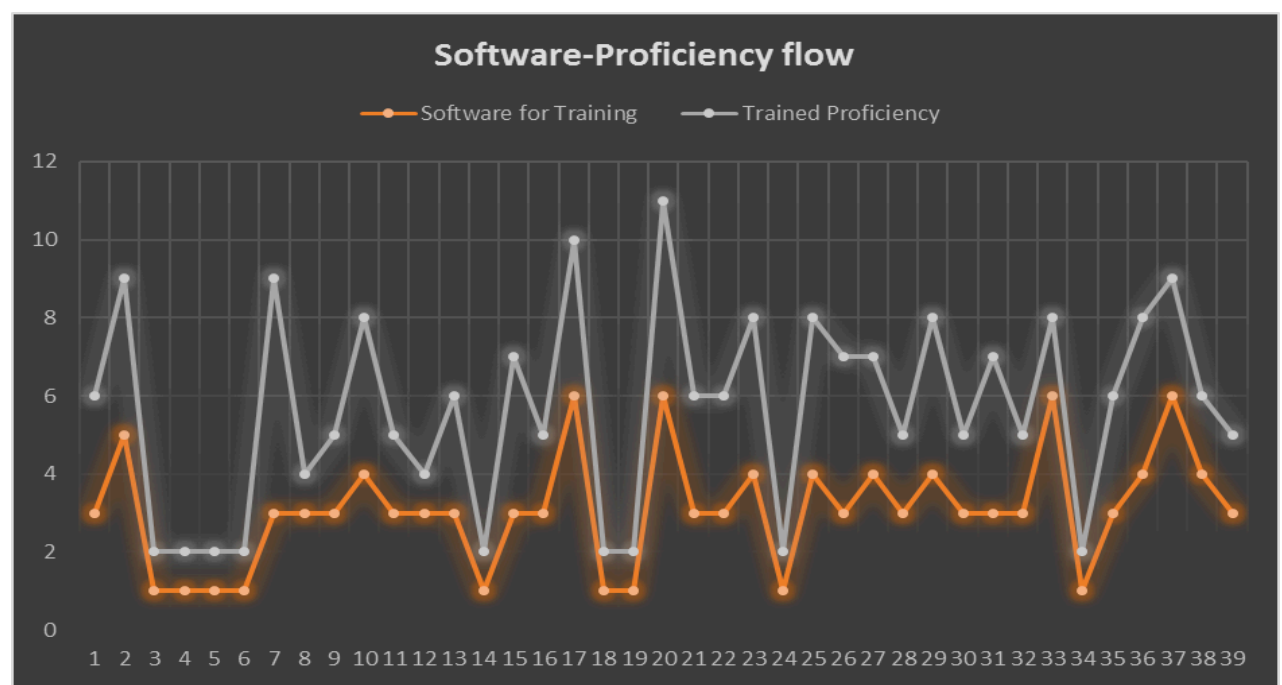

Figure 9: The software-proficiency flow chart

\section{Correlations amongst variables}

To examine the infrastructure role on the training, correlation analysis was done between variables hardware and software on the one hand, and proficiency level of training received by students on the other. It was found that there is significant (refer to Table 4) correlation between both availability and quantity of computers with the level of training offered and proficiency level that students graduate with. The correlation between hardware (available computers) and the training received by students is positive with 0.659 significant at 0.01 level. Moreover, the availability of software is most critical to the level of training; the correlation is positively strong with a significance of 0.804 also at 0.01 level (refer to Table 4). In this context, the proficiency level at graduation significantly (0.903) depends on the proficiency level of training.

On the other hand, the academic qualification of trainers does not have significance in the training proficiency whether at training or at graduation (Table 5). Although the academic qualification is significant, "train the trainers" is another strategy to maintain knowledge transfer and keep the trainers up-todate on latest technology.

Table 4: Correlations

\begin{tabular}{|c|c|c|c|c|c|c|c|c|c|}
\hline & & Dept. & $\begin{array}{c}\text { Academic } \\
\text { Qualificatio } \\
\text { n }\end{array}$ & $\begin{array}{c}\text { Availabilit } \\
\text { y of } \\
\text { computer } \\
\text { lab. }\end{array}$ & $\begin{array}{l}\text { Number of } \\
\text { computers }\end{array}$ & $\begin{array}{l}\text { Highest } \\
\text { available } \\
\text { software }\end{array}$ & $\begin{array}{l}\text { Highest } \\
\text { software } \\
\text { for } \\
\text { training }\end{array}$ & $\begin{array}{l}\text { Training } \\
\text { proficiency }\end{array}$ & $\begin{array}{c}\text { Proficiency at } \\
\text { graduation }\end{array}$ \\
\hline \multirow{3}{*}{ Department } & $\begin{array}{l}\text { Pearson } \\
\text { Correlation } \\
\end{array}$ & 1 & -.147 & .209 & -.253 & $-.380^{*}$ & $-.385^{*}$ & -.189 & -.055 \\
\hline & $\begin{array}{l}\text { Sig. (2- } \\
\text { tailed) }\end{array}$ & & .373 & .201 & .120 & .017 & .015 & .248 & .741 \\
\hline & $\mathrm{N}$ & 39 & 39 & 39 & 39 & 39 & 39 & 39 & 39 \\
\hline
\end{tabular}




\begin{tabular}{|c|c|c|c|c|c|c|c|c|c|}
\hline \multirow{5}{*}{$\begin{array}{l}\text { Academic } \\
\text { Qualificatio } \\
\mathrm{n}\end{array}$} & Pearson & -.147 & 1 & -.129 & .209 & .208 & .293 & .284 & .118 \\
\hline & \multicolumn{9}{|l|}{ Correlation } \\
\hline & Sig. (2- & \multirow{2}{*}{\multicolumn{2}{|c|}{.373}} & .433 & .201 & .204 & .071 & .080 & .475 \\
\hline & tailed) & & & & & & & & \\
\hline & $\mathrm{N}$ & 39 & 39 & 39 & 39 & 39 & 39 & 39 & 39 \\
\hline \multirow{5}{*}{$\begin{array}{l}\text { Availability } \\
\text { of computer } \\
\text { lab. }\end{array}$} & Pearson & .209 & -.129 & 1 & $-.733^{* *}$ & $-.796^{* *}$ & $-.781 * *$ & $-.671^{* *}$ & $-.653^{* *}$ \\
\hline & \multicolumn{9}{|l|}{ Correlation } \\
\hline & Sig. (2- & .201 & .433 & & .000 & .000 & .000 & .000 & .000 \\
\hline & tailed) & & & & & & & & \\
\hline & $\mathrm{N}$ & 39 & 39 & 39 & 39 & 39 & 39 & 39 & 39 \\
\hline \multirow{5}{*}{$\begin{array}{l}\text { Highest } \\
\text { available } \\
\text { software }\end{array}$} & Pearson & - & .208 & $-.796^{* *}$ & $.779^{* *}$ & 1 & $.877^{* *}$ & $.673^{* *}$ & $.556^{* *}$ \\
\hline & Correlation & $.380^{*}$ & & & & & & & \\
\hline & Sig. (2- & .017 & .204 & .000 & .000 & & .000 & .000 & .000 \\
\hline & tailed) & & & & & & & & \\
\hline & $\mathrm{N}$ & 39 & 39 & 39 & 39 & 39 & 39 & 39 & 39 \\
\hline \multirow{5}{*}{$\begin{array}{l}\text { Highest } \\
\text { software for } \\
\text { training }\end{array}$} & Pearson & - & .293 & $-.781^{* *}$ & $.742^{* *}$ & $.877^{* *}$ & 1 & $.804^{* *}$ & $.649^{* *}$ \\
\hline & Correlation & $.385^{*}$ & & & & & & & \\
\hline & Sig. (2- & .015 & .071 & .000 & .000 & .000 & & .000 & .000 \\
\hline & tailed) & & & & & & & & \\
\hline & $\mathrm{N}$ & 39 & 39 & 39 & 39 & 39 & 39 & 39 & 39 \\
\hline \multirow{4}{*}{$\begin{array}{l}\text { Training } \\
\text { proficiency }\end{array}$} & Pearson & -.189 & .284 & $-.671^{* *}$ & $.659^{* *}$ & $.673^{* *}$ & $.804^{* *}$ & 1 & $.903^{* *}$ \\
\hline & Correlation & & & & & & & & \\
\hline & $\begin{array}{l}\text { Sig. (2- } \\
\text { tailed) }\end{array}$ & .248 & .080 & .000 & .000 & .000 & .000 & & .000 \\
\hline & $\mathrm{N}$ & 39 & 39 & 39 & 39 & 39 & 39 & 39 & 39 \\
\hline \multirow{5}{*}{$\begin{array}{l}\text { Proficiency } \\
\text { at } \\
\text { graduation }\end{array}$} & Pearson & -.055 & .118 & $-.653^{* *}$ & $.556^{* *}$ & $.556^{* *}$ & $.649^{* *}$ & $.903^{* *}$ & 1 \\
\hline & Correlation & & & & & & & & \\
\hline & Sig. (2- & .741 & .475 & .000 & .000 & .000 & .000 & .000 & \\
\hline & tailed) & & & & & & & & \\
\hline & $\mathrm{N}$ & 39 & 39 & 39 & 39 & 39 & 39 & 39 & 39 \\
\hline
\end{tabular}

*. Correlation is significant at the 0.05 level (2-tailed).

**. Correlation is significant at the 0.01 level (2-tailed).

Table 5: Correlations

\begin{tabular}{ccc}
\hline & Academic Qualification & $\begin{array}{c}\text { Trained } \\
\text { Proficiency }\end{array}$ \\
\hline Academic Qualification & 1 & 1 \\
Trained Proficiency & 0.118 & 1 \\
\hline
\end{tabular}

\section{Conclusions and recommendation}

This piece of work aimed to: determine the capacity of Nigerian universities in providing BIM tools training for BIM adoption in AEC through the assessment of Nigerian universities' infrastructure (hardware and software) capacity; skilled 
personnel; $\mathrm{CAD}(\mathrm{s})$ training proficiency levels; as well as the outcome of the trained students at graduation.

Architectural technology has a strong interest in this subject matter. More than $50 \%$ of the modelling software is also acquired by architectural technology schools. Hence, architectural technology schools are at the forefront of CAD (BIM stage 1) training. Considering that most institutions have relatively sufficient hardware, the institutions can therefore be considered physically (on a hardware basis) ready to offer BIM tools training at BIM stage 1 (Succar and Kassem, 2015); however technically they are not ready because there is no modelling software or intensive training.

The construction industry in Nigeria lacks experts and trained personnel in collaboration tools (Hamma-adama et al, 2018), and most graduates are generally trained on 'file based collaboration' - 2D and 3D CAD. A clear obstacle can be noted at the institutional level regarding training on collaborative working for the industry's applicability and consumption. Although the proficiency level received at graduation mainly ranges from basic to practical application, so too the higher the software sophistication, the higher the proficiency level of training received and acquired by students. With only $13.3 \%$ modelling software training across the institutions (mostly architectural schools), there is very little contribution to the industry. In brief, this study reveals that the type and proficiency level of training offered to students in the subject poses a high possibility of manpower shortage for BIM adoption at stage 1 (modelling) as well as collaborative working, i.e. BIM stage 2 (Succar and Kassem, 2015). Therefore the adoption rate is likely to be low due to the continuous shortage of trained graduates on BIM tools. To achieve sufficient training on BIM tools, availability of software in these institutions is critical.

To achieve significant levels of BIM tools training, a strategic plan for the tools training at the institutional level is recommended. This will involve introduction of new modules in the institutions' curricula; procurement of at least modelling and collaborative software (BIM stage 1 and 2); more training of the trainers; and involvement of professional bodies for the purpose of continuous professional development.

The above findings and recommendation are limited to the study area (Nigeria), although some could be applicable to other developing countries as they mostly have the same trend.

\section{References:}

Ballantyne, C. 2003. "Measuring quality units: considerations in choosing mandatory questions", Evaluations and Assessment Conference: A Commitment to Quality, University of South Australia, Adelaide, pp. 24.

Barison, M.B. and Santos, E.T., 2010, June. BIM teaching strategies: an overview of the current approaches. In Proc., ICCCBE 2010 international conference on computing in civil and building engineering.

Cao, D., Li, H. \& Wang, G. 2014, "Impacts of isomorphic pressures on BIM adoption in construction projects", Journal of Construction Engineering and Management, vol. 140, no. 12, pp. 04014056.

Casey, M.J., 2008. BIM in education: focus on local university programs. In Building Smart Alliance national Conference Engineering 83 Construction, 2008, Washington DC, USA.

Chico, C. 2008. "What impact does using building information modeling have on teaching estimating to construction management students?" 
Clevenger, C.M., Ozbek, M., Glick, S. \& Porter, D. 2010. "Integrating BIM into construction management education", EcoBuild Proceedings of the BIM-Related Academic Workshop.

Construction, M. 2008. "Smart Market Report: Building Information Modeling (BIM)—Transforming Design and Construction to Achieve Greater Industry Productivity", The McGraw-Hill Companies, New York. ISBN.

Construction, M.H., 2014. The Business Value of BIM for Construction in Major Global Markets: How contractors around the world are driving innovations with Building Information Modelling. Smart MarketReport.

Dankwort, C.W., Weidlich, R., Guenther, B. \& Blaurock, J.E. 2004. "Engineers' CAx education-it's not only CAD", Computer-Aided Design, vol. 36, no. 14, pp. 1439-1450.

Eadie, R., Browne, M., Odeyinka, H., McKeown, C. \& McNiff, S. 2013. "BIM implementation throughout the UK construction project lifecycle: An analysis", Automation in Construction, vol. 36 , pp. $145-151$.

Egan, J. 1998, "Rethinking construction, construction task force report for department of the environment, transport and the regions", ed: HMSO, London.

Field, D.A. 2004. "Education and training for CAD in the auto industry", Computer-Aided Design, vol. 36 , no. 14 , pp. 1431-1437.

Froise, T. \& Shakantu, W. 2014. "Diffusion of innovations: an assessment of building information modelling uptake trends in South Africa", Journal of Construction Project Management and Innovation, vol. 4, no. 2, pp. 895-911.

Hamma-adama, M., Salman, H.S. and Kouider, T., 2018. Diffusion of innovations: the status of building information modelling uptake in Nigeria. Journal of Scientific Research 8 Reports, 17(4), 1-12. DOI: $10.9734 /$ JSRR/2017/38711

Migilinskas, D., Popov, V., Juocevicius, V. and Ustinovichius, L., 2013. The benefits, obstacles and problems of practical BIM implementation. Procedia Engineering, 57, pp.767-774.

Nulty, D.D. 2008, "The adequacy of response rates to online and paper surveys: what can be done?" Assessment 83 evaluation in higher education, vol. 33, no. 3, pp. 301-314.

Ogunrayewa, M.O. 2013. "New Trends in Architectural Curriculum Development-A Panacea for Sustainable Architectural Education in Nigeria." Journal of the Association of Architectural Educators (AARCHES-J), vol. 1, pp. 3-8.

Ogunsote, O.O., Prucnal-Ogunsote, B. \& Umaru, N.A. 2007. "Curricular Anatomy of the CAD Proficient Architecture Graduate in Nigeria", Journal of the Association of Architectural Educators in Nigeria (AARCHESJ), 6 (1), 99, vol. 109.

Oladele, M. 2009. "The Socio-Cultural Relevance of Architectural Education in Nigeria in a Global Age"

Onwuka, E. 2009, "Reshaping engineering education curriculum to accommodate the current needs of Nigeria", Educational Research and Reviews, vol. 4, no. 7, pp. 334-339.

Rezgui, Y., Hopfe, C.J. \& Vorakulpipat, C. 2010. "Generations of knowledge management in the architecture, engineering and construction industry: An evolutionary perspective", Advanced Engineering Informatics, vol. 24, no. 2, pp. 219-228.

Rossignac, J. 2004. "Education-driven research in CAD", Computer-Aided Design, vol. 36, no. 14, pp. 1461-1469.

Sabongi, F.J. \& Arch, M. 2009. "The Integration of BIM in the Undergraduate Curriculum: an analysis of undergraduate courses", Proceedings of the 45th ASC Annual Conference, The Associated Schools of Construction, pp. 1.

Sacks, R. and Barak, R., 2009. Teaching building information modeling as an integral part of freshman year civil engineering education. Journal of professional issues in engineering education and practice, 136(1), pp.30-38.

Succar, B., 2009. Building information modelling framework: A research and delivery foundation for industry stakeholders. Automation in construction, 18(3), pp.357-375.

Succar, B. and Kassem, M., 2015. Macro-BIM adoption: Conceptual structures. Automation in Construction, 5\%, pp.64-79.

Sylvester, K.E. \& Dietrich, C. 2010. "Evaluation of building information modeling (BIM) estimating methods in construction education", Proceedings of 46 th ASC Annual International Conference, April, pp. 7.

Walasek, D. \& Barszcz, A. 2017. "Analysis of the Adoption Rate of Building Information Modeling [BIM] and its Return on Investment [ROI]", Procedia Engineering, vol. 172, pp. 1227-1234.

Ye, X., Peng, W., Chen, Z. \& Cai, Y. 2004. "Today's students, tomorrow's engineers: an industrial perspective on CAD education", Computer-Aided Design, vol. 36, no. 14, pp. 1451-1460. 